\title{
MOLECULAR STUDIES ON PASTEURELLA SPECIES ISOLATED FROM DUCKS
}

\author{
SELIM- AMANY, O. ${ }^{1}$; ALRAFIE- AMIRA, S. ${ }^{2}$; SABRY, E.O. ${ }^{3}$ and ELSAYED- HEMAT S. ${ }^{4}$ \\ ${ }^{1,3,4}$ Animal Health Research Institute Banha, Zagazig Branch \\ ${ }^{2}$ Animal Health Research Institute, Banha, Egypt
}

Received: 28 September $2017 \quad$ Accepted: 31 October 2017

\begin{abstract}
The present study was conducted on 150 ducks collected from ten farms in Kaliobia Governorate suspected to be suffering from Pasteurellosis that is manifested by respiratory signs, sudden death, and nervous manifestation. Samples were taken from the liver, spleen, heart and lung and examined bacteriologically. A total of 33 Pasteurella isolates were isolated, 25 isolates were Pasteurella multocida and 8 isolates were Pasteurella pneumotropica. The invitro-antibiotic sensetivity test showed that Pasteurella isolates were highly sensitive to florofinicole followed by ciprofloxacine and enrofloxacin. Meanwhile, the isolates showed absolute resistance to erythromycin followed by gentamycin, amoxicillin, oxytetracycline, penicillin, tobramycin and naldixic acid for both types of Pasteurella. PCR results showed that cytotoxic protein (toxA) gene and fimbrial protein (ptfA) gene were detected in 4 out of 10 studied strains for both genes. Sequences of toxA and $p t f A$ genes were submitted to Gen Bank and assigned accession numbers were MF167359 and MF382009, respectively.
\end{abstract}

Key words: Pasteurella multocida- Pasteurella pneumotropica- toxA- ptfA -antibiotic sensitivity test- PCRducks.

\section{INTRODUCTION}

Pasteurella multocida belonging to family Pasteurellaceae is a ubiquitous organism affecting multi host species, thus causing several diseases like fowl cholera in poultry, snuffles in rabbits, haemorrhagic septicaemia in cattle and buffalo, enzootic bronchopneumonia in cattle, sheep, and goats and atrophic rhinitis in swine, (Harper et al., 2006, Dziva et al., 2008 and Markey et al., 2013). Past. multocida is identified as a major threat for a poultry industry which hamper the profitable poultry production (Sellyei et al., 2010).

Clinically ducks associated with pasterullosis showed anorexia, depression and respiratory manifestation (Eldin and Reda, 2016), lameness and corneal turbidity (Takahashi et al., 1996). On postmortem, petechial and ecchymotic hemorrhages were common, particularly in subepicardial (heart) and subserosal (liver) locations. The liver was swollen accompanied with multiple, small, necrotic foci. Pneumonia and air sacculitis were commonly seen (Fouad and Hebat Allah, 2008 and Mohan and Pradeep Kumar, 2008).

Corresponding author: Dr. SELIM- AMANY, O.

E-mail address: slimeamany004@yahoo.com

Present address: Animal Health Research Institute Banha, Zagazig Branch.
Based on capsular antigens, P. multocida strains are differentiated into five serogroups i.e., type A causing fowl cholera pathogen and bovine shipping fever, type B causing hemorrhagic fever in ungulates, type $\mathrm{D}$ causing atrophic rhinitis in swine, type $\mathrm{E}$, an African serotype, infecting cattle and buffalo; and type $\mathrm{F}$ also causing fowl cholera (Carter, 1955 and Rimler et al., 1987). Several studies detected the virulence profiling of $P$. multocida isolates from different hosts (Ferreira et al., 2012; Furian et al, 2013; Katsuda et al., 2013 and Verma et al., 2013). These virulence factors (VFs) and outer membrane proteins are important for pathogenesis, functionality, protective immunity and vaccine development against P. multocida infections (Hatfaludi et al., 2010 and Katsuda et al., 2013). The main virulence factors of Pasteurella were Endotoxins (lipopolysaccharides, LPS) that are particularly important in the septicaemic diseases such as fowl cholera and bovine haemorrhagic septicaemia. P. multocida serotyes A and D can produce a cytotoxic protein named $P$. multocida toxin (PMT), which stimulates cellular cytoskeletal rearrangements and growth of fibroblasts. Interestingly, avirulent PMT-positive strains and virulent PMT-negative strains have both been reported. However, PMT plays a role in atrophic rhinitis (mild to severe destruction of porcine nasal turbinate bones) and Filamentous hemagglutinins (PfhB1 and $P f h \mathrm{~B} 2)$, surface fibrils ( $H s f_{\_} 1$ and $\left.H f s_{-} 2\right)$, and fimbrial subunits (PtfA, FimA, Flp_1, Flp_2) are Adhesion to host cells, chemotaxis (Dashe et al., 
2015), the ptfA gene of which assemble to form type 4 fimbriae on the bacterial surface (Sellyei et al., 2010).

Past. pneumotropica was found to be latent in laboratory rats, mice, guinea pigs and hamsters (Baker, 2003). Naturally occurring disease which has been recorded in laboratory mice include pneumonia, conjunctivitis, otitis, abortion and abscesses (Charles, 2009 and Justin et al., 2014). As duck cholera is contiguous, septicemic and fatal disease for ducks and little studies were investigated with the virulence of this pathogen so the present study was conducted to isolate pasteurella species from ducks and study their virulence factors.

\section{MATERIALS AND METHODS}

\section{Sample collection:}

\subsection{Samples collection}

A total of 150 diseased pekin ducks of different ages (3 weeks-7weeks) were collected from 10 different duck farms at Kaliobia Governorate. The collected ducks showed mortalities ranged from 30-40\%. No previous history for vaccination of collected ducks against duck cholera. Samples were taken from liver, heart, lung, kidney and spleen of each duck for bacteriological examination.

\subsection{Studies the bacteriological character and their virulence factor}

The surface of organs was seared by hot spatula, and then a sterilized loopfuls were inoculated onto Tryptone soya broth and incubated aerobically at $37^{\circ} \mathrm{C}$ for 24 hours. A loopful from incubated Tryptone soya broth was streaked onto sheep blood agar, Baird Parker agar with $1 \mathrm{ml}$ of $0.1 \%$ of crystal violet as Pasteurella has ability to grow in presence of $0.1 \%$ crystal violet and egg yolk tollurite (Melody et al., 1994); Mac Conkey's agar, all plates were incubated for 24 hours at $37^{\circ} \mathrm{C}$. The developed colonies were picked up and subcultured for purification. The purified colonies were morphologically identified by Gram stain and Leishman's staining technique and biochemical tests (Carter, 1984 and Markey et al., 2013).

\subsection{In-Vitro antibiotic sensitivity test:}

The Pasteurella isolates were subjected to the sensitivity test against different antibiotics, using the disc and agar diffusion method (Finegold and Martin, 1982) for their susceptibility against 10 anti microbial agents representing classes of different antimicrobial agents (ciprofloxacin, gentamycin, tobramycin, amoxicillin, erythromycin, enrofloxacin, oxytetracycline, penicillin, naldixic acid and florofinicol)

2.4. Detection of tox $\mathrm{A}$ and ptfA genes of Pasteurella multocida by PCR according to (Sambrook et al., 1989):

PCR was applied on random10 selected Pastereulla multocida isolates by using two sets of primers for detection of two virulence genes Cytotoxic protein (toxA) and fimbrial protein ( $p t f \mathrm{~A})$

\section{DNA extraction:}

Using the QIAamp DNA Mini kit (Qiagen, Germany, $\mathrm{GmbH}$ ) with modifications from the manufacturer's recommendations.

Oligonucleotide Primer: Primers used were supplied from Metabion (Germany) and listed in Table (1).

PCR amplification: Primers were utilized in a $25-\mu 1$ reaction containing $12.5 \mu \mathrm{l}$ of Emerald Amp Max PCR Master Mix (Takara, Japan), 1

\section{Analysis of the PCR Products:}

The products of PCR were separated by electrophoresis on $1.5 \%$ agarose gel (Applichem, Germany, $\mathrm{GmbH}$ ) in $1 \mathrm{x}$ TBE buffer at room temperature.

Table 1: Primers sequences, target genes, amplicon sizes and cycling conditions.

\begin{tabular}{|c|c|c|c|c|c|c|c|c|}
\hline \multirow{2}{*}{$\begin{array}{c}\text { Target } \\
\text { gene }\end{array}$} & \multirow[t]{2}{*}{ Primers sequences } & \multirow{2}{*}{$\begin{array}{c}\text { Amplified } \\
\text { segment } \\
\text { (bp) }\end{array}$} & \multirow{2}{*}{$\begin{array}{c}\text { Primary } \\
\text { Denaturation }\end{array}$} & \multicolumn{3}{|c|}{ Amplification ( 35 cycles) } & \multirow{2}{*}{$\begin{array}{l}\text { Final } \\
\text { extn. }\end{array}$} & \multirow[t]{2}{*}{ Ref. } \\
\hline & & & & $\begin{array}{c}\text { Secondary } \\
\text { denaturation }\end{array}$ & Annealing & Extension & & \\
\hline \multirow[t]{3}{*}{$\operatorname{toxA}$} & CTTAGATGAGC & 864 & $94^{\circ} \mathrm{C} /$ & $94^{\circ} \mathrm{C}$ & $48^{\circ} \mathrm{C}$ & $72^{\circ} \mathrm{C}$ & $72^{\circ} \mathrm{C}$ & \multirow{8}{*}{$\begin{array}{l}\text { Tang } e t \\
a L ., 2009\end{array}$} \\
\hline & GACAAGG & & $5 \mathrm{~min}$. & $30 \mathrm{sec}$. & $40 \mathrm{sec}$ & $50 \mathrm{sec}$. & $10 \mathrm{~min}$. & \\
\hline & $\begin{array}{c}\text { GAATGCCACAC } \\
\text { CTCTATAG }\end{array}$ & & & & & & & \\
\hline \multirow[t]{5}{*}{$p t f A$} & TGTGGAATTCA & 488 & $94^{\circ} \mathrm{C} /$ & $94^{\circ} \mathrm{C}$ & $55^{\circ} \mathrm{C}$ & $72^{\circ} \mathrm{C}$ & $72^{\circ} \mathrm{C}$ & \\
\hline & $\begin{array}{c}\text { GCATTTTAGTGT } \\
\text { GTC }\end{array}$ & & $5 \mathrm{~min}$. & $30 \mathrm{sec}$. & $40 \mathrm{sec}$ & $40 \mathrm{sec}$. & $10 \mathrm{~min}$. & \\
\hline & TCATGAATTCTT & & & & & & & \\
\hline & ATGCGCAAAAT & & & & & & & \\
\hline & CCTGCTGG & & & & & & & \\
\hline
\end{tabular}

Sequencing protocol: By Dye termination method (Sanger et al., 1977). 


\section{Steps of sequence analysis:}

1- The received sequence was imported into alignment window with the downloaded highly similar sequences into BIOEDIT version 7.0.4.1 software. And MEGA 5.05 DNA alignment tool

2- Sequence submission was conducted following the instructions offered by the web tool Bankit of GenBank

http://www.ncbi.nlm.nih.gov/WebSub/?tool=genbank with the following numbers: bankit2012800 seq for toxA and bankit2026599 for ptfA gene of pasteurella multocida.

\section{RESULTS}

\section{Clinical cases:}

The most common observed clinical signs showed by affected ducks were sudden death, greenish diarrhea, nervous manifestation, locomotory disturbance, depression and mucus discharge from mouth and nostrils. The post mortem lesions showed swollen liver with necrotic foci, hemorrhages on heart, pneumonia and airsacculitis.

\section{Bacteriological examination:}

The bacteriological examination of samples collected from 150 diseased ducks revealed the recovery of 33 pasteurella isolates, where 25 isolates $(76 \%)$ were identified as Pasteurella multocida and 8 isolates (24\%) were identified as Pasteurella pnemotropica. the isolated bacterial colonies on blood agar plates were small, glistening, mucoid, dew drop like and non-haemolytic, and appeared as Gram-negative coccobacilli when stained with Gram's stain. Leishman's staining technique revealed bipolar microrganisms. Moreover, the isolates failed to grow on MacConkey agar.

\section{Antibiotic sensitivity test:}

The results of invitro- antibiotic sensitivity test (Table, 2) revealed that the isolated Pasteurella species were highly sensitive to florofinicole $(84.8 \%)$ followed by ciprofloxacine $(60.6 \%)$ and enrofloxacin $(51.5 \%)$. Meanwhile they were highly resistance to erythromycin $(100 \%)$, followed by gentamycin $(84.8 \%)$; amoxicillin, oxytetracycline and penicillin (69.7\% per each); tobramycin (66.7) and naldixic acid $(63.6 \%)$ for both types of Pasteurella.

Table 2: Antibiotic sensitivity for 33 Pasteurella species isolates by disc diffusion method:

\begin{tabular}{|c|c|c|c|c|c|c|c|}
\hline \multirow{2}{*}{$\begin{array}{r}\text { Sensitivity } \\
\text { Antibiotics agent }\end{array}$} & \multicolumn{2}{|c|}{ Sensitive } & \multicolumn{2}{|c|}{ Intermediate } & \multicolumn{2}{|c|}{ Resistance } & \multirow[t]{2}{*}{ A.A } \\
\hline & No. & $\% *$ & No & $\% *$ & No & $\% *$ & \\
\hline Ciprofloxacin $(10 \mu \mathrm{g})$ & 20 & 60.6 & 0 & 0.0 & 13 & 39.4 & $\mathrm{~S}$ \\
\hline Gentamycin $(10 \mu \mathrm{g})$ & 5 & 15.1 & 0 & 0.0 & 28 & 84.8 & $\mathrm{R}$ \\
\hline Tobramycin & 11 & 33.3 & 0 & 0.0 & 22 & 66.7 & $\mathrm{R}$ \\
\hline Amoxicillin $(20 \mu \mathrm{g})$ & 10 & 30.3 & 0 & 0.0 & 23 & 69.7 & $\mathrm{R}$ \\
\hline Erythromycin $(10 \mu \mathrm{g})$ & - & - & 0 & 0.0 & 33 & 100 & $\mathrm{R}$ \\
\hline Enrofloxacin $(10 \mu \mathrm{g})$ & 17 & 51.5 & 3 & 9.1 & 16 & 48.4 & $\mathrm{~S}$ \\
\hline Oxytetracyclin $(10 \mu g)$ & 10 & 30.3 & 0 & 0 & 23 & 69.7 & $\mathrm{R}$ \\
\hline Pencillin 10 units & 10 & 30.3 & 2 & 6.0 & 23 & 69.7 & $\mathrm{R}$ \\
\hline Naldixic acid $(30 \mu g)$ & 12 & 36.4 & 0 & 0.0 & 21 & 63.6 & $\mathrm{R}$ \\
\hline Florofinicol $(30 \mu \mathrm{g})$ & 28 & 84.8 & 0 & 0.0 & 5 & 15.1 & $\mathrm{~S}$ \\
\hline
\end{tabular}

$\% *$ in relation to total number of pasteurella isolates (33), A.A Antibiogram Activity, $\mathrm{S}$ sensitive, $\mathrm{R}$ resistance

\section{PCR results:}

The results of PCR (Table, 3) showed that, toxA and ptfA genes were detected in 4 strains of 10 examined ones for each. 
Table 3: Virulence gene toxA and $p t f \mathrm{~A}$ detected by PCR test in P.multocida

\begin{tabular}{cccc}
\hline Sample & toxA & Results \\
\cline { 2 - 4 } & $\mathbf{1}$ & - & - \\
\hline $\mathbf{2}$ & + & + \\
\hline $\mathbf{3}$ & + & + \\
\hline $\mathbf{4}$ & - & - \\
\hline $\mathbf{5}$ & - & + \\
\hline $\mathbf{6}$ & + & - \\
\hline $\mathbf{7}$ & - & + \\
\hline $\mathbf{8}$ & + & - \\
\hline $\mathbf{9}$ & - & - \\
\hline
\end{tabular}

A set of primers were designed for amplification of toxA and ptfA genes in 10 pasteurella multocida isolates to be used in a PCR. Analysis of the PCR products on agrose gel electrophoresis revealed successful amplification of ptfA gene at 488bp (Fig. 1) and toxA gene at 864bp (Fig. 2).

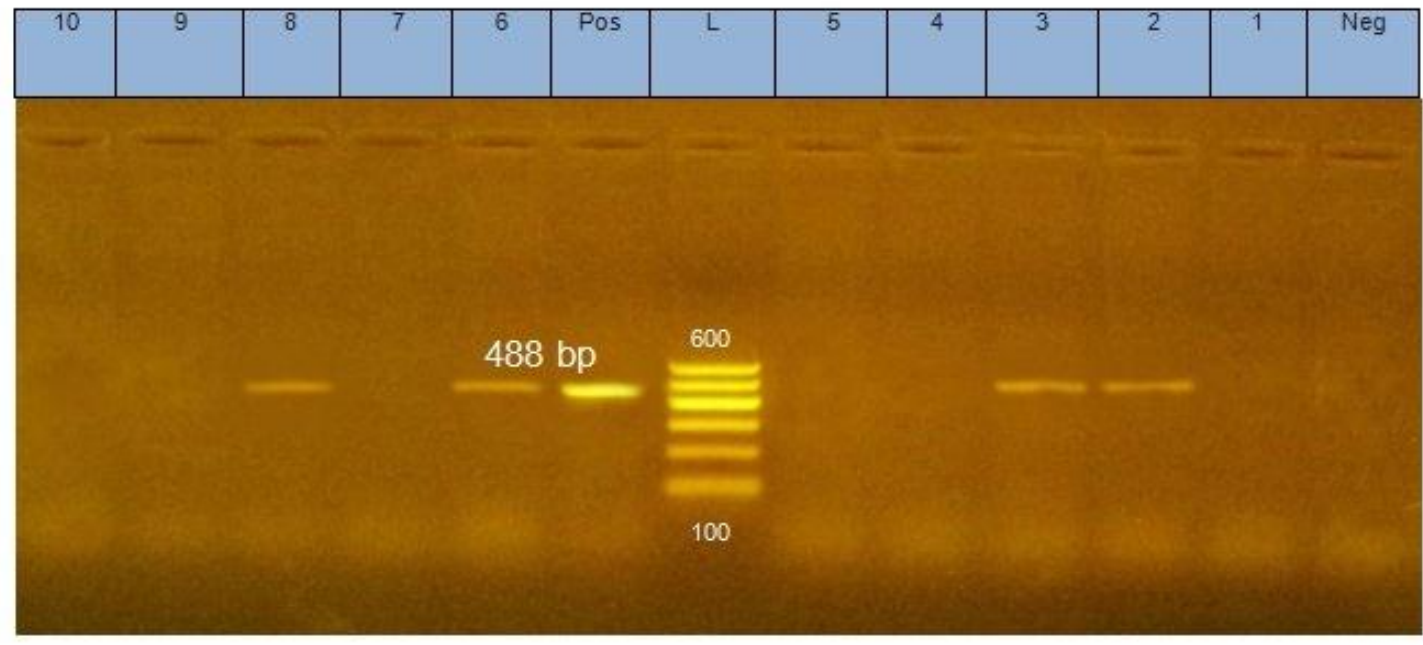

Fig. 1: Agarose gel electrophoresis of ptfA gene gene in 10 Pasteurella multocida isolates, M: 100 bp DNA marker, lanes (2, 3, 6 and 8): positive amplification of ptfAgene at $488 \mathrm{bp}$, Positive control: standered strain from AHRI Dokki, Negative control.

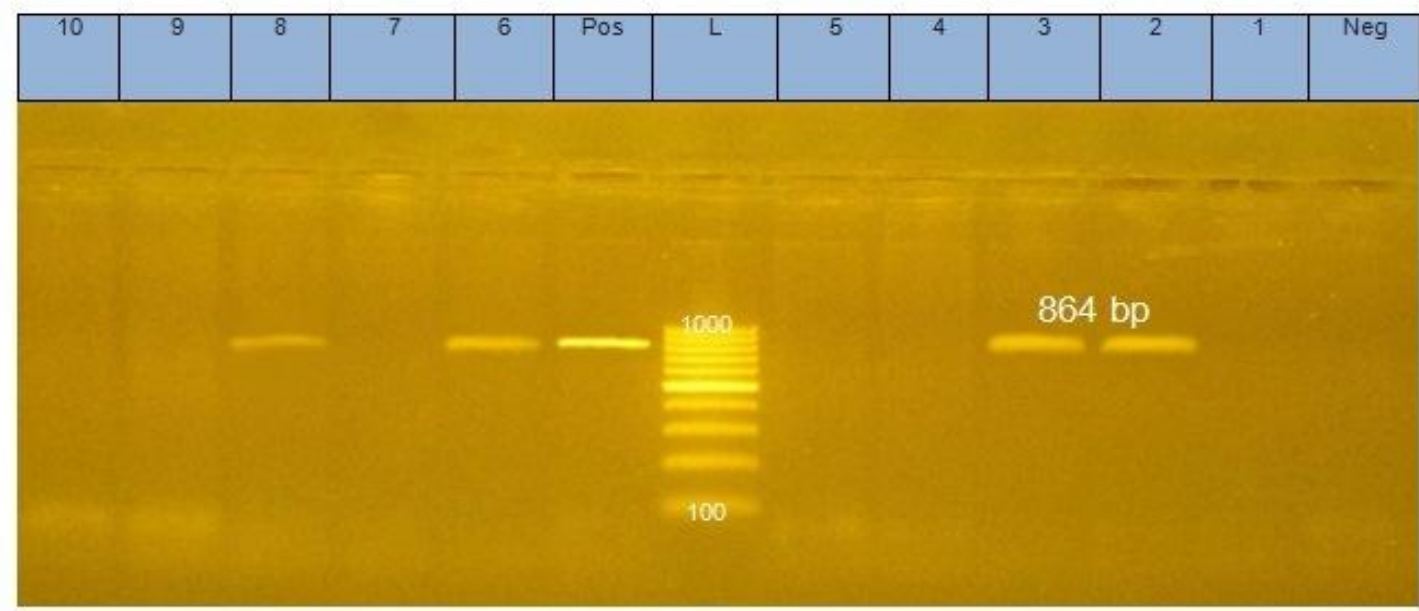

Fig. 2: Agarose gel electrophoresis of toxA gene in 10 Pasteurella multocida isolates, M: 100 bp DNA marker, lanes (2, 3, 6 and 8): positive amplification of toxA gene at 864bp, Positive control: standered strain from AHRI Dokki, Negative control.

\section{Nucleotide sequence accession number}

Partial gene sequence of toxA and ptfA of Pasteurella multocida isolate was submitted to Gen Bank and assigned accession number were MF167359 and MF382009, respectively. 


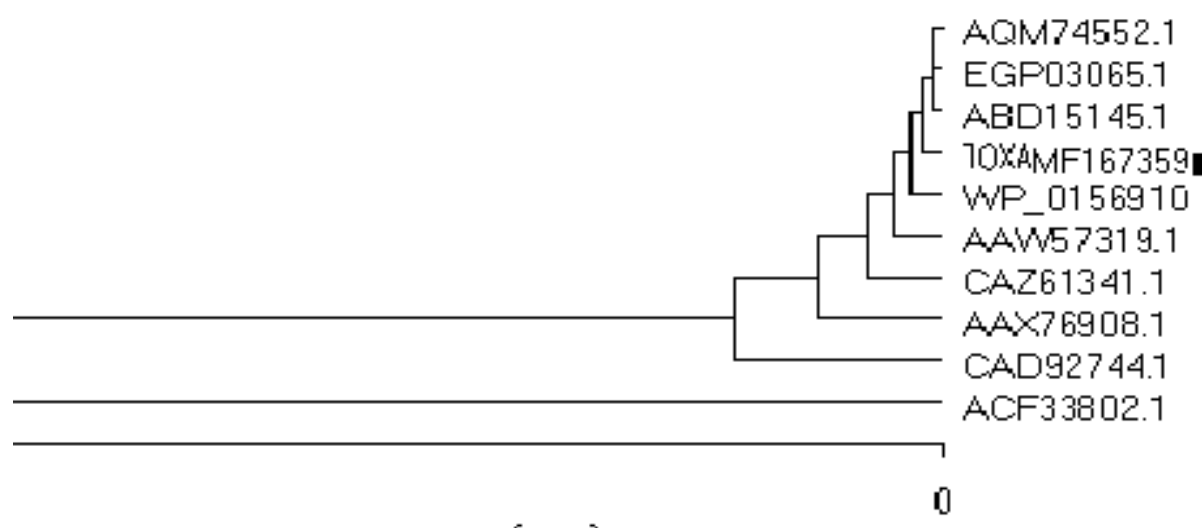

Amino deid Substitutions $(x 100)$

pgylogenetic tree of toxAMF197359 of study and some other in gene bank

Fig. 3: Phylogenetic analysis of nucleotide of toxA MF167359 in comparison with other selected strain form gene bank

Percent Identity

\begin{tabular}{|c|c|c|c|c|c|c|c|c|c|c|c|}
\hline & $\mathbf{1}$ & $\mathbf{2}$ & $\mathbf{3}$ & $\mathbf{4}$ & $\mathbf{5}$ & $\mathbf{6}$ & $\mathbf{7}$ & $\mathbf{8}$ & $\mathbf{9}$ & $\mathbf{1 0}$ & \\
\hline $\mathbf{1}$ & & 989 & 989 & 989 & 989 & 989 & 986 & 985 & 985 & 96.7 & $\mathbf{1}$ \\
\hline $\mathbf{2}$ & 0.0 & & 100.0 & 100.0 & 100.0 & 100.0 & 996 & 100.0 & 100.0 & 100.0 & $\mathbf{2}$ \\
\hline $\mathbf{3}$ & 0.0 & 0.0 & & 100.0 & 100.0 & 100.0 & 996 & 100.0 & 100.0 & 100.0 & $\mathbf{3}$ \\
\hline $\mathbf{4}$ & 0.0 & 0.0 & 0.0 & & 100.0 & 100.0 & 996 & 100.0 & 100.0 & 100.0 & $\mathbf{4}$ \\
\hline $\mathbf{5}$ & 0.0 & 0.0 & 0.0 & 0.0 & & 100.0 & 996 & 100.0 & 100.0 & 100.0 & $\mathbf{5}$ \\
\hline $\mathbf{6}$ & 0.0 & 0.0 & 0.0 & 0.0 & 0.0 & & 996 & 100.0 & 100.0 & 100.0 & $\mathbf{6}$ \\
\hline $\mathbf{7}$ & 0.4 & 0.4 & 0.4 & 0.4 & 0.4 & 0.4 & & 995 & 995 & 989 & $\mathbf{7}$ \\
\hline $\mathbf{8}$ & 0.0 & 0.0 & 0.0 & 0.0 & 0.0 & 0.0 & 0.5 & & 100.0 & 100.0 & $\mathbf{8}$ \\
\hline $\mathbf{9}$ & 0.0 & 0.0 & 0.0 & 0.0 & 0.0 & 0.0 & 0.5 & 0.0 & & 100.0 & $\mathbf{9}$ \\
\hline $\mathbf{1 0}$ & 0.0 & 0.0 & 0.0 & 0.0 & 0.0 & 0.0 & 1.1 & 0.0 & 0.0 & & $\mathbf{1 0}$ \\
\hline & $\mathbf{1}$ & $\mathbf{2}$ & $\mathbf{3}$ & $\mathbf{4}$ & $\mathbf{5}$ & $\mathbf{6}$ & $\mathbf{7}$ & $\mathbf{8}$ & $\mathbf{9}$ & $\mathbf{1 0}$ & \\
\hline
\end{tabular}

TOXA MF167359

CAD92744.1

AAX76908.1

CAZ61341.1

AAW57319.1

WP_01 5691094.1

ACF33802.1

ABD15145.1

AQM 74552.1

EGPCO065.1

Fig. 4: Nucleotide identities and divergence of toxA MF167359 compared to other selected strains.

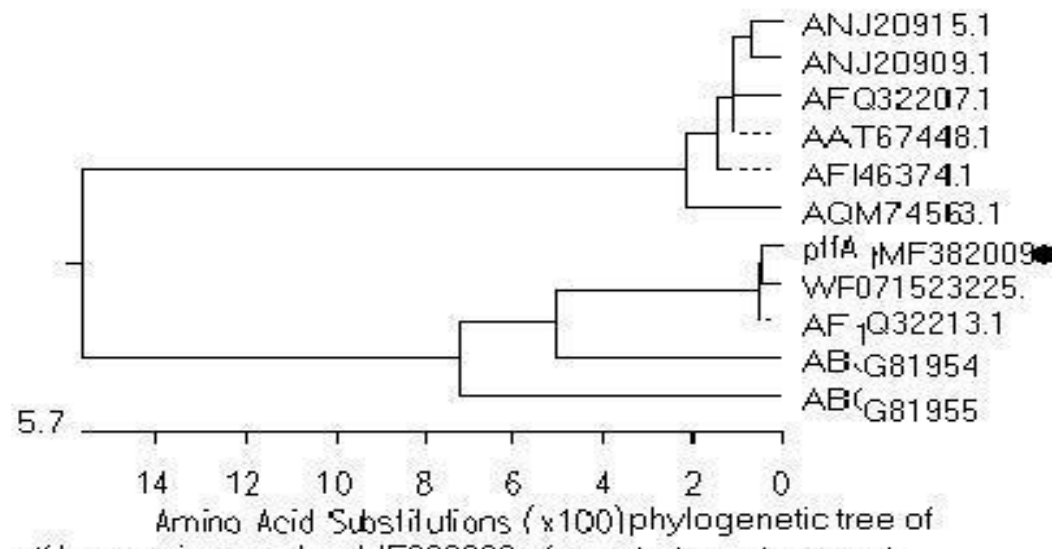

pttA accesion number MF382009 of our study and someot

other accesion numbers recorded in genbank

Fig. 5: Phylogenetic analysis of nucleotides of ptfA MF382009 in comparison with other selected strain form gene bank 
Percent Identity

\begin{tabular}{|c|c|c|c|c|c|c|c|c|c|c|c|c|}
\hline & $\mathbf{1}$ & $\mathbf{2}$ & $\mathbf{3}$ & $\mathbf{4}$ & $\mathbf{5}$ & $\mathbf{6}$ & $\mathbf{7}$ & $\mathbf{8}$ & $\mathbf{9}$ & $\mathbf{1 0}$ & $\mathbf{1 1}$ & \\
\hline $\mathbf{1}$ & & 100.0 & 99.3 & 91.0 & 91.0 & 79.9 & 792 & 78.5 & 785 & 77.8 & 78.5 & $\mathbf{1}$ \\
\hline $\mathbf{2}$ & 0.0 & & 99.3 & 91.0 & 91.0 & 79.9 & 792 & 785 & 785 & 77.8 & 78.5 & $\mathbf{2}$ \\
\hline $\mathbf{3}$ & 0.7 & 0.7 & & 90.3 & 903 & 79.2 & 785 & 77.8 & 77.8 & 77.1 & 77.8 & $\mathbf{3}$ \\
\hline $\mathbf{4}$ & 9.6 & 9.6 & 10.4 & & 83.3 & 736 & 736 & 729 & 736 & 72.9 & 72.9 & $\mathbf{4}$ \\
\hline $\mathbf{5}$ & 9.6 & 9.6 & 10.4 & 189 & & 736 & 729 & 722 & 722 & 71.5 & 72.2 & $\mathbf{5}$ \\
\hline $\mathbf{6}$ & 235 & 23.5 & 24.5 & 325 & 325 & & 97.2 & 96.5 & 965 & 95.8 & 96.5 & $\mathbf{6}$ \\
\hline $\mathbf{7}$ & 24.5 & 24.5 & 25.4 & 325 & 336 & 2.8 & & 993 & 993 & 98.6 & 99.3 & $\mathbf{7}$ \\
\hline $\mathbf{8}$ & 254 & 25.4 & 26.4 & 336 & 34.7 & 3.6 & 0.7 & & 986 & 97.9 & 98.6 & $\mathbf{8}$ \\
\hline $\mathbf{9}$ & 254 & 25.4 & 26.4 & 325 & 34.7 & 3.6 & 0.7 & 1.4 & & 97.9 & 98.6 & $\mathbf{9}$ \\
\hline $\mathbf{1 0}$ & 264 & 26.4 & 27.4 & 33.6 & 358 & 4.3 & 1.4 & 2.1 & 2.1 & & 97.9 & $\mathbf{1 0}$ \\
\hline $\mathbf{1 1}$ & 254 & 25.4 & 26.4 & 33.6 & 34.7 & 3.6 & 0.7 & 1.4 & 1.4 & 2.1 & & $\mathbf{1 1}$ \\
\hline & $\mathbf{1}$ & $\mathbf{2}$ & $\mathbf{3}$ & $\mathbf{4}$ & $\mathbf{5}$ & $\mathbf{6}$ & $\mathbf{7}$ & $\mathbf{8}$ & $\mathbf{9}$ & $\mathbf{1 0}$ & $\mathbf{1 1}$ & \\
\hline
\end{tabular}

Dtf

MF382009

AFQ322131

WP_071523225.1

ABG819551

ABG81954.1

AQM745631

A.AT674481

AN 20915.1

A.F 46374.1

AFQ32207.1

AN 20909.1

Precent identfy between pasteurella ptfAgene (MF382009, and some strains in gene bank

Fig. 6: Nucleotide identities and divergence of ptfA MF382009 compared to other selected strains.

\section{Phylogenetic analysis and nucleotide comparison}

The nucleotides sequences of toxA MF167359 gene and ptfA MF382009 gene showed percent identity with the selected pasteurella multocida strains published on gene bank ranged from 96.7 to $100 \%$ (fig 3-fig4) and 71.5 to $100 \%$ (fig5-fig6), respectively. The selected sequences were isolated from chicken and wild birds.

\section{DISCUSSION}

Duck cholera is one of the important disease affecting ducks causing severe economic losses; therefore our investigation was carried out to isolate pasteurella species from ducks collected from ten farms in Kaliobia Governorate. In our study the affected ducks showed sudden death (30-40\%), greenish diarrhea, nervous and respiratory manifestation. The post mortem lesions showed swollen liver with necrotic foci, hemorrhages on heart, pneumonia and airsacculitis. Similar clinical signs and postmortem picture were reported in ducks associated with pasterullosis by Fouad and Hebat Allah, 2008; Mohan and Pradeep Kumar, 2008 and Eldin and Reda, 2016.

The bacteriological examination of samples collected from 150 diseased ducks revealed isolation of 33 pasteurella isolates. The isolated bacterial colonies on blood agar plates were small, glistening, mucoid, dew drop like and non-haemolytic. They appeared as Gram-negative coccobacilli when stained with Gram's stain. Leishman's staining technique revealed bipolar microrganisms. These features were in agreement with previous researches (Akhtar, 2013; Belal, 2013 and Ievy et al., 2013).

In the present study $P$. multocida were isolated from ducks by total percent of $16.7 \%$, (25/150). Nearly similar results were recorded by Kumar et al. (2004) and Sayedun et al. (2015) who isolated P. multocida from avian species including ducks with percentage of $34 \%$ and 11.42 , respectively but disagreed with Kamruzzaman et al. (2016) who isolated P. multocida from ducks with higher percentage of $59.72 \%$. Moreover 5.3\% (8/33) P. pneumotropica strains were isolated. Theses isolates were currently isolated from rat or guinea pig bite wound (Anne-Lise et al., 2005), its occurrence in ducks indicate the role of rodent as reservoir for transmission of the disease to other susceptible flocks and pay attention to application of biosecurity in ducks farms.

The results of invitro- antibiotic sensitivity test (Table, 2) revealed that, the isolated pasteurella species were highly sensitive to florofinicole $(84.8 \%)$ followed by ciprofloxacine $(60.6 \%)$ and enrofloxacin $(51.5 \%)$. Meanwhile they were highly resistance to erythromycin (100\%), followed by gentamycin $(84.8 \%)$; amoxicillin, oxytetracycline and penicillin (69.7\% per each); tobramycin (66.7) and naldixic acid $(63.6 \%)$ for both types of Pasteurella. The obtained results are not in agreement with (Kamruzzaman et al., 2016) who cited that ciprofloxacin was the most effective antibiotic by $95 \%$ followed by gentamycin $(85 \%)$, tetracycline and amoxicillin ( $75 \%$ per each). Also our results differed from that obtained by Dashe et al. (2015) who showed that ciprofloxacin, streptomycin and gentamycin were highly effective against $P$. multocida. On the other hand, Maity et al. (2012) reported that $P$. multocida was sensitive to amoxiclav, chloramphenicol, and moderately sensitive to amikacin, cefotaxime, neomycin and norfloxacin but resistant to ciprofloxacin and lomefloxacin. The variation in the sensitivity grade among various studies may be due to over or limited previous exposure and indiscriminate use of 
antibiotics as feed additives and/or preventive or curative agents.

In our study tox $\mathrm{A}$ and $p t f \mathrm{~A}$ genes were detected in 4 strains of 10 examined ones for each. Similar results were recorded by Thales et al. (2016) who detected toxA and ptfA in Pasteurella isolates. Strains toxA MF167359 and ptfA MF382009 in our study shared nucleotides identities 96.7 to $100 \%$ and 71.5 to $100 \%$, respectively with selected pasteurella multocida sequences published on gene bank. Most of the aligned sequences were isolated from chicken as AQM74552.1, which Submitted (27-AUG-2016) while others were isolated from wild birds as EGP03065.1 which Submitted (22-JUN-2011). Data indicated that application of strategies to control the access of wild birds to duck farms where they act as reservoir for the pasterullosis, also the data revealed cross infection between ducks and chicken which give great attention to avoid multi species breading.

\section{CONCLUSION}

Finally the present study concluded that pasterullosis (duck cholera) is a serious disease in duck farms with economic importance. Application of good biosecurity in duck farms to avoid transmission of $p$. pneumotropica from rodent to duck is needed important, the use of effective vaccination against duck cholera to control the disease in ducks; Moreover Florofinicol is the drug of choice for treatment of Pasteurella species in ducks.

\section{REFERENCES}

Akhtar, M. (2013): Isolation, identification and characterization of Pasteurella multocida from chicken and development of oil based vaccine, MS thesis, Department of Microbiology and Hygiene, Bangladesh Agricultural University, Mymensingh.

Anne-Lise Gautier, Damien Dubois, Françoise Escande, Jean-Loup Avril, Patrick Trieu-Cuot, Olivier Gaillot (2005): Rapid and Accurate Identification of Human Isolates of Pasteurella and Related Species by sequencing the sodA GeneJ ClinMicrobiol. May; 43(5): 2307-2314.

Baker, DG. (2003): Natural Pathogens of laboratory Animals: their effects on research. Washington, D.C: ASM press; 2003.385 pp.

Belal, SMSH. (2013): Occurrence of Pasturellosis and Newcastle disease in indigenous chicken in Sirajgonj district. Bangladesh Journal of Veterinary Medicine, 11: 97-105.

Carter, GR. (1955): A haemagglutination test for the identification of serological types. American Journal of Veterinary Research.16, 481-48.

Carter, GR. (1984): Pasteurella. Bergeys Manual of Systematic Bacteriology. Vol: I. Williams and
Wilkins (Krieg, N. R. and J. G. Holt, Eds), Baltimore. Pp. 552-558.

Charles River Laboratories (2009): Technical sheet on Pasteurella pneumotropica. http://www. criver.com/ SiteCollectionDocuments/ rm_ld_ r_Pasteurella

Dashe Yakubu; RajiMoshood; Abdu Paul; Oladele Blessing and Oluwadare (2015): Phenotypic Characteristics of Pasteurella Multocida Isolated From Commercial Chickens Affected By Fowl Cholera in Jos, Nigeria. J. World's Poult. Res. 5(3): 59-63.

Dziva, F.; Muhairwa, AP.; Bisgaard, M. and Christensen, H. (2008): Diagnostic and typing options for investigating diseases associated with Pasteurella multocida. Veterinary Microbiology, vol. 128, no. 1-2, pp. 1-22.

Eldin, W.F.S. and Reda L.M. (2016): Epidemiological prevalence of Pasteurella multocida in ducks. Japanese Journal of Veterinary Research. 64 (supplement 2): S251-S255.

Ferreira, TSP.; Felizardo, MR. and Sena de Gobbi, DD. (2012): Virulence genes and antimicrobial resistance profiles of Pasteurella multocida strains isolated fromrabbits in Brazil. The Scientific World Journal, vol., Article ID 685028, 6 pages.

Finegold, SM. and Martin, S. (1982): Diagnostic Microbiology $6^{\text {th }}$ ed. the C.V. Mosby Company, St. Louis Tranto, London. Wiener Tierarstilich Mschr. 6:233-236.

Fouad, I.A. and Hebat Allah, A.E.M. (2008): Bacteriological and pathological studies of pasteurella haemolytica in ducks in Assuit governorate. Assuit. Vet. Med. J. no 116, January

Furian, TQ; Borges, KA. and Rocha, SLS (2013): Detection of virulence-associated genes of Pasteurella multocida isolated from cases of fowl cholera by multiplex-PCR. Pesquisa Veterin 'aria Brasileira, vol. 33, no. 2, pp. 177182

Harper, M.; Boyce, JD. and Adler, B. (2006): Pasteurella multocida pathogenesis: 125 years after Pasteur. FEMS Microbiology Letters, vol. 265, no. 1, pp. 1-10.

Hatfaludi, T.; Al-Hasani, K.; Boyce, JD. and Adler, $B$. (2010): Outer membraneproteins of Pasteurella multocida. Vet. Microbiol. 2010; 144:1-17.38.

Ievy, S.; Khan, MRF.; Islam, MA. and Rahman, MB. (2013): Isolation and identification of Pasteurella multocida from chicken for the preparation of oil adjuvanted vaccine. Bangladesh Journal of Veterinary Medicine, 2: $1-4$.

Justin, W.T.; April, M.W.; Kurt, J.G.; Adam, S.B.; Jeffrey, A.F. and David, G.B. (2014): Elimination of Pasteurella pneumotropica from a Mouse Barrier Facility by Using a Modified 
Enrofloxacin Treatment Regimen Journal of the American Association for Laboratory Animal Science

Kamruzzaman1, M.; Islam, M.; Hossain, MM.; Hassan, MK.; Kabir, MHB.; Sabrin, MS. and Khan, MSR. (2016): Isolation, Characterization and Antibiogram Study of Pasteurella multocida Isolated from Ducks of Kishoreganj District, Bangladesh. International Journal of Animal Resources, Volume-1, Number-1, January, Page 69 to 76.

Katsuda, K.; Hoshinoo, K.; Ueno, Y.; Kohmoto, M. and Mikami, O. (2013): Virulence genes and antimicrobial susceptibility in Pasteurella multocida isolates from calves. Veterinary Microbiology, vol. 167, no. 3-4, pp. 737-741.

Kumar, AA.; Shivachandra, SB.; Biswas, B.; Singh, $V B$. and Srivastava, SK. (2004): Prevalent serotypes of Pasteurella multocida isolated from different animal and avian species in India Veterinary Research Communication, 28: 657-667.

Maity, DK.; Chatterjee, A.; Guha, C. and Biswas, U. (2012): Pasteurellosis in duck in west Bengal. Exploratory Animal and Medcal Research, 1(2):119-123.

Markey, B.; Leonard, F.; Archambault, M.; Cullinane, A. and Maguire, D. (2013): Clinical veterinary microbiology second Ed. MOSBYELSEVIER Chapter 21:307- 316.

Melody K. Moore; Lidija Cinjak Chubbs and Robert J. Gates (1994): Anew selective enrichment procedure for isolating Pasteurella multocida from avain and environmental samples. Avian Diseases 38: 317-324.

Mohan, K. and Pradeep Kumar, PG. (2008): Pasturellosis in a Duck. Veterinary World Vol.1, No.12, December, PP.367.

Rimler, R.B.; Rhoades, K.R. and Jones, T.O. (1987): Serological and immunological study of Pasteurellamultocida strains that produced septicaemia in fallowdeer. Veterinary Record, 121, 300-301.

Sambrook, J.; Fritsch, E.F. and Montias, T. (1989): Molecular Biology. In: Molecular cloning.
Laboratory manual, Second Edition. Cold Spring Harbor Laboratory press, USA.

Sanger, F.; Nicklen, S. and Coulson, AR. (1977): "DNA sequencing with chain-terminating inhibitors". Proc. Natl. Acad. Sci. U.S.A. 74 (12): 5463-467.

Sayedun Nahar Pannal, KHM; Nazmul Hussain Nazir, M; Bahanur Rahman, Sultan Ahamed, MD; Golam Saroare; Shovon Chakma; Tazrin Kamal and Ummay Habiba Majumder (2015): Isolation and molecular detection of Pasteurella multocida Type A from naturally infected chickens, and their histopathological evaluation in artificially infected chickens in Bangladesh. J. Adv. Vet. Anim. Res., 2(3): 338-345.

Sellyei, B1.; Bányai, K. and Magyar, T. (2010): Characterization of the ptfA gene of avian Pasteurella multocida strains by allele-specific polymerase chain reaction. J Vet Diagn Invest. (4):607-610.

Tang, X.; Zhao, Z.; Hu, J; Wu, B.; Cai, X.; He, Q. and Chen, H. (2009): Isolation, Antimicrobial Resistance, and Virulence Genes of Pasteurella multocida Strains from Swine in China. J. Clin. Microbiol. April; 47(4): 951958.

Thales QuediFurian; Karen Apellanis Borges; Vanessa Laviniki; Silvio Luis da Silveira Rocha; CamilaNeves de Almeida; Vladimir Pinheiro do Nascimento; Carlos TadeuPippi Salle; Hamilton Luiz de Souza Moraes (2016): Virulence genes and antimicrobial resistance of Pasteurella multocida isolated from poultry and swine Brazilian journal of microbiology 47, 210-216.

Takahashi, S.; Sato, H.; Yamada. T.; Takenouchi, T.; Sawada, T.; Nakano, K. and Saito, H. (1996): Outbreaks of fowl cholera in Muscovy ducks (Cairina moschata) on a farm in Aomori Prefecture. J. Vet. Med. Sci. 58(3): 269-272.

Verma, S., Sharma, M. and Katoch, S. (2013): Profiling of virulence associated genes of Pasteurella multocida isolated from cattle. Veterinary Research Communications, vol. 37, no. 1 , pp. $83-89$.

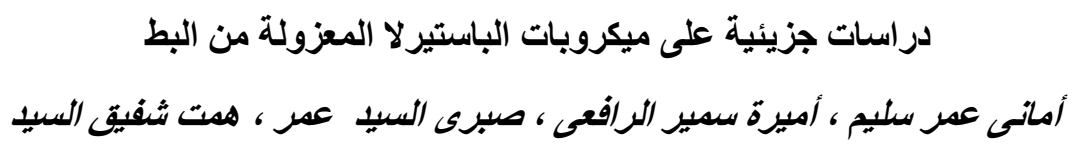

Email: slimeamany004@yahoo.com Assiut University web-site: www.aun.edu.eg

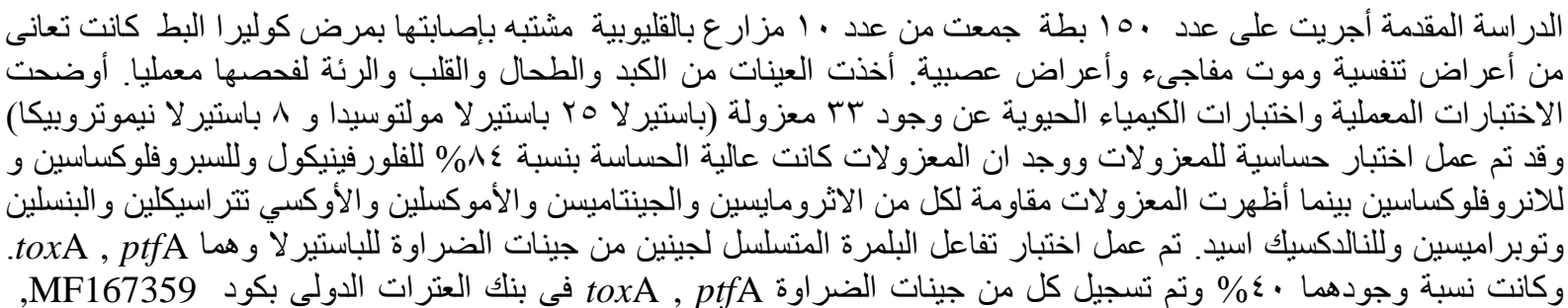

